Teknokultura. Revista de Cultura Digital y Movimientos Sociales

ISSNe: $1549-2230$

http://dx.doi.org/10.5209/TEKN.63098

\title{
The roles of social media in 21 st century populisms: US presidential campaigns
}

\author{
George Julian Hendrix ${ }^{1}$
}

Recibido: 30 de enero de 2019 / Aceptado: 21 de marzo de 2019 Open peer reviews

\begin{abstract}
In the United States, "populist" is a controversial and often misunderstood signifier in common discourse. In addition, the current state of mass media and introduction of social networking tools has created a hyper-partisan spectacle of politics - especially during presidential campaign seasons. Through the review of literature on populism, traditional and social media, and presidential campaigning in the United States, this article constructs a new view on the relationship between these three topics in the 21 st century. Important steps in this article's process include defining populism and its place within campaigning and media; presenting social media as a political tool and a dynamic personalized informer; and analyzing the US presidential elections since 2008. Resultantly, because the trends of online activity, on the part of both the citizen and the candidate, impact social media users' self-informing and political engagement, the process of selecting a new US president has become more susceptible to various populist practices in this century than before.
\end{abstract}

Keywords: personalization; political engagement; self-informing.

\section{[es] Los Papeles de las redes sociales en el populismo del siglo 21: campañas presidenciales estadounidenses}

Resumen. En el discurso de los Estados Unidos «populista» es un significante polémico y a menudo no entendido. Además, se ha creado un espectáculo muy parcial de la política debido al estado actual de los medios masivos y a la introducción de las redes sociales. A través del análisis de literaturas sobre el populismo, los medios tradicionales y sociales y la campaña presidencial de los Estados Unidos, se construye en este artículo una nueva interpretación sobre la relación entre estos tres temas en el siglo XXI. Las etapas analizadas incluyen la definición del populismo y su posición con respecto a la campaña y a los medios; la presentación de las redes sociales como herramientas políticas e informantes personalizados dinámicos; y analizar las elecciones presidenciales estadounidenses desde 2008. Por ello, argumento que debido a que las tendencias de las actividades en línea, por parte del ciudadano y del candidato, afectan a las habilidades de los usuarios de las redes sociales para informarse y participar en la política, el proceso de elegir un nuevo presidente de los Estados Unidos se ha vuelto más propenso a varias prácticas populistas en este siglo que antes.

Palabras clave: autoinformarse; participación política; personalización.

Summary. 1. Introduction. 2. Defining populism and its relation to media. 3. Defining social media and personalization. 4. Analyzing US Presidential campaigns incorporating social media. 5. Concluding remarks. 7. Acknowledgments. 6. References.

Cómo citar: Julian Hendrix, G. (2019). The roles of social media in 21st century populisms: US presidential campaigns, en Teknokultura. Revista de Cultura Digital y Movimientos Sociales, 16(1), 1-10.

1 East Carolina University (USA)

E-mail: hendrixg15@students.ecu.edu 


\section{Introduction}

Contemporary politics are characterized by their relationship with social media. Since the early to mid $20^{\text {th }}$ century, technological advancements in media have been harnessed by various politicians to their advantage. More recently, a partisan mass media and now the introduction of social networking applications have become the standard, all of which create a political spectacle to be consumed. I discuss how this (social) media spectacle relates to populism in the $21^{\text {st }}$ century, specifically to the "Trump phenomenon" in a context of its own relation to the Obama campaigns. This discussion further proposes whether instances of populism may have a unique propensity to garner undue support and success in this century, in part as a result of developing trends among the usage of social media.

Through the analyses of Mazzoleni, Stewart, and Horsfield's (2003) descriptions of populist movements and Cass Sunstein's ideas on the "personalization" of social media, I infer that yes, this may be the case. Mazzoleni, Stewart, and Horsfield's work was written before the age of social media and the current political climate, but by transferring their concepts onto the use of the online in politics, rather than (or in addition to) traditional media, the contemporary age of mobilization can be understood. Taking from Jody Baumgartner (2017), Stephen Farnsworth (2018), and others' publications, explanations of the methodologies from the past three US presidential campaigns serve to reinforce this premise of social media as a necessary, or at the least relevant, component of $21^{\text {st }}$ century populisms.

This article presents the intersection of populisms, the unique methods of discourse used by both "populist" actors and some traditional politicians alike, and the introduction of social media as a political device, as a valid area for future discussion and research. This assertion is credited on the presentation of social media as a salient factor in populist mobilization and on the analysis of the change in how both candidates and voters have used social media in campaigns since 2008. By demonstrating that social media has not only become an integral part of the contemporary US presidential campaign but has also evolved to almost cater to populist tactics, this article draws attention to the possibility of the campaigns' susceptibility to populisms and a need for further investigation.

When analyzing populist actors or even traditional politicians utilizing populist tactics, contemporary literature has mostly viewed the issue as a content of actions and discourse with traditional media as the only relay to the people. Both novel and established tactics are being utilized; with that being said this article aims to promote the inclusion of or primary investigation into social media for future analyses on populism and media as the digital tools are now common place. While this article focuses solely on social media use during US presidential campaigns, the rise of populist actors internationally draws a need for similar analysis on the role played by types of social media in those respective campaigns.

\section{Defining populism and its relation to media}

To start, populism as a term is often misused or abused and may be difficult to be confined to an explicit definition. No consistent attributable ideology exists; from the end of WWII towards the turn of the century, populist movements around the globe 
have gradually moved from left to right-wing positions, with some even claiming to be neither (Mazzoleni, Stewart \& Horsfield, 2003, p. 4). Themes of opportunism or demagogy have been proposed as defining features as well, however this is not over-encompassing and could apply to various political campaigns instead. Attempts to define populism have rather taken a discursive route, focusing on passions and morality, antagonisms and empty signifiers (Mudde \& Kaltwasser, 2012, pp. 5-6).

An initial definition of this discourse is taken from Ernesto Laclau's On Populist Reason, 2005. Laclau claims "Populism is a discourse that articulates a chain of equivalence around an empty signifier and defined by an antagonistic frontier". Cas Mudde further explains this definition as moral politics, the "pure people" versus the "corrupt elite". It is a movement that forms its identity through passion, utilizing a charismatic leader who links very different demands as a simple fix through the will of the people and who creates the recognition of a common enemy or enemies (2012, pp. 5-6).

Now, for the intents and purposes of my paper, I focus solely on populism in the $21^{\text {st }}$ century (within the US political theatre). By this time, populist movements definitely adhere to the above definitions. They also begin to be associated with rightwing positions and are undoubtedly characterized by a "media factor", as maintained by Betz and Immerfall, 1998. Still not yet in the age of social media, the decades around the turn of the century contain a conservative-reactionary force that was distinguished from the fascist right and had especially "media-genic personal qualities". These qualities are "... highly emotional, slogan-based, tabloid style language, combining verbal radicalism and symbolic politics with the tools of contemporary political marketing to disseminate their ideas among the electorate" (as cited in Mazzoleni, Stewart \& Horsfield, 2003, pp. 3-5). These media qualities are populist tactics but may indeed still be used by traditional politicians; if the actor is a political outsider, revels in controversy, and explicitly utilizes the "them" vs "us" dynamic, he or she may be deemed a "populist".

Further, this media attribute of populism describes how the movements are given their momentum through intense coverage by what has become a sensationalized mass media. The populist leaders have become irresistible to journalists due to their novelty and dramatic flair. Various strategies the populists use to acquire and maintain media attention, whether intentional or not, are covered by Mazzoleni, Stewart, and Horsfield (2003), and while written before the age of Trump, the parallels are uncanny. They detail identification as a media "underdog", usage of unmediated forms of communication such as frequent intense rallies (or today the additional use of social media), and attacks on the media itself. In addition, media outlets often focus on the "personalization" frame of issues, especially various behavioral or spoken gaffes by populist leaders (2003, p. 230).

Mazzoleni, Stewart, and Horsfield outline four phases of the media's relationship with populist forces. First is the ground-laying step, which is the indirect increase of society's sense of psychological insecurities. Negative public opinions are exacerbated through the sensationalizing of stories for a profit; this allows for a populist movement to take advantage of the people's fears. Next is the insurgent phase, when a populist candidate starts to be given immense free coverage. The tone of the coverage, whether sympathetic or condemning, is not important, for the public becomes familiarized with the populist rhetoric regardless. In an air of boredom with the status quo politics, the novelty and drama of the populist 
is once again sensationalized to normalcy and legitimacy. The third phase, the established phase, occurs after this legitimacy is achieved and the media begins to downplay the significance of a candidate and views him as not a threat. Finally, if applicable, is the decline phase, which would be the loss of coverage for the individual and party (2003, pp. 219-24).

The pattern for populist movements is established and with the integration of social media into campaigning, a new era must be understood. The desires of eligible voters can now be appealed to directly without the traditional middle-man of radio, TV, and written press. Also, the ground-laying phase from before can now be produced from both the tools of social media and the users themselves. Populism has quickly entered a new age and my thoughts are that social media will begin and continue to produce populist movements and better enable their success compared to earlier in the century before social media.

\section{Defining social media and personalization}

Now that the use of populism is explained, the role of social media is next. More specifically, the sociological phenomena stemming from the usage of social media is detailed through the spreading of information and forming of opinions. Could a possible uniqueness borne to $21^{\text {st }}$ century instances of populisms be correlated to a "breeding ground" for populist movements among social media and similar platforms? Ideas including group polarizations, "cyber" cascades, online ideological targeting, and the force of false or misleading information could be associated with methods to power plausibly utilized by a new contemporary populist incarnation.

Overall, being that this century has so far been characterized as operating fundamentally around the use of the internet, my discussion of social media will refer to various online platforms and the traffic therein. Search engines, media and news platforms, etc. may be mentioned, but for this paper I cover the "social media" tools that accrue the persistent attention of many. This "social media" refers to "Internet-based platforms that allow the creation and exchange of user-generated content, usually using either mobile or web-based technologies", as defined by Helen Margetts et al. (2015, p. 5), in Political Turbulence: How Social Media Shape Collective Action (as cited in Sunstein, 2017, p. 22). It would especially incorporate major platforms such as Facebook and Twitter, but also Instagram and Snapchat, and to an extent sites like YouTube, blogs, and forums. In essence, I am referring to any hosting service that allows opinion to be formed and shared, information to be spread, and audiences to be reached. An explanation is needed as to why these new information tools could have (or have had) a skewing effect on democratic participation regarding ideological positioning and self-informing.

In this new millennium, previous sociological patterns may have precedent but as society reforms, so must the methods of acquiring and giving knowledge and power. Previously, one's architecture of control over forming a worldview was based in a public sphere. One of course had presuppositions and biases but would nonetheless encounter opposing views regularly among that which was sought out (Sunstein, 2017, pp. 1-6). This was due in part to the unique passage of information solely through reputable and/or established general-interest in- 
termediaries - newspapers, magazines, TV, and radio broadcasters. These third parties have been subdued by the special-interest intermediaries of private social networking applications, the "social media" (pp. 18-20). So now the traditional news mediums are often accessed through another online medium; this online medium being both curtailed by the respective owners and administrators but also through the "personalization" of the user himself.

To explain this medium "personalization", I introduce the idea of the "DailyMe", as used by Cass Sunstein in his \#Republic (2017). Through the active sorting and segregation of posts by the user himself and the built-in algorithm of the platform to adjust the feed according to the user's behaviors, this user effectively is created an echo chamber of self-confirming and targeted information, removing many opposing posts that one could otherwise encounter. In addition to the influence users themselves have, is the ability to be ideologically targeted in this domain. As previously mentioned, the built-in algorithms monitor the "clicking behavior" of users in order to select posts more likely to be interacted with and make new suggestions in a similar fashion. Along those lines, with targeted articles of information can come targeted political advertisements. The online medium, the "DailyMe", we create for ourselves should be quite capable of presenting to a certain ideologically aligned individual with a compatible message from a political figure or organization.

Also from \#Republic, according to a 2016 poll by the Pew Research Center, consumption of current events, politics, etc. has been relocating to this personalized online sphere for a significant percentage of the population: with $59 \%$ of US adults getting this information from Twitter and 66\% from Facebook (from the same poll, $67 \%$ of US adults use Facebook, so possibly $44 \%$ of the population is using Facebook explicitly for this purpose) (2016, p. 126). This shift from direct access of general-interest intermediaries to personalized special-interest screens could be claimed to be producing ideological polarization and informational isolation among participating parties.

Now, supposing the above claim to be true, my proposition is one of whether this effect could relate to a rise of populist tendencies. For if a polarized group discussing in an echo chamber could cause a tide of misinformation or emotional unrest with just enough influence to upset a status quo, it could be a step. A false misleading, or propagandized post circulating in a certain network managing to gain momentum through an informational cascade, without need for verification by exposed consumers, could completely change the political atmosphere among a group. Allcott and Gentzkow (2017) detail four potential social costs of the consumption of this misinformation. First, mistaken consumers would fare for the worse due to having less-accurate beliefs. Moreover, these less-accurate beliefs may "... reduce positive social externalities, undermining the ability of the democratic process to elect high-quality candidates" (Allcott and Gentzkow, 2017, p. 219). In addition, these false or misleading news pieces could cause consumers to become even more skeptical of legitimate sources, blurring the lines between the real and the fake. Later on, these social results may initiate lacks of demand on the consumer's part and initiative of an established source's part for reporting that is unbiased, accurate, and reliable. These costs could only perpetuate the tendencies of polarization and psychological malaise and uncertainty, plausible ingredients for a populist catch-hold. 


\section{Analyzing US Presidential campaigns incorporating social media}

The respective campaign methodologies from the 2016 US presidential election should be viewed in a context of constructed reaction and result from the 2008 and 2012 presidential campaigns. So as these two prior election seasons, 2016 saw social media as an additional requisite for reaching the electorate. However, while social media maintained, perhaps even increased, its quantitative presence, the quality of and manner of participation in its political usage undoubtedly had undergone a negative shift. Since 2008, the efforts by President Obama, and his opponents during his tenure, to shape this qualitative aspect of social media in politics laid the groundwork for President Trump's online success, in turn setting a new precedent for future populist politics.

To explain this qualitative shift in social media usage, I take from Jody C. Baumgartner and Terri L. Towner's (2017, p. 156) The Internet and the 2016 Presidential Campaign. In this, the use of social media during campaigns is conceptualized along a continuum of user threshold levels. These levels being: 1) campaign engagement (high threshold); 2) interactive expression (medium threshold); and 3) information seeking (low threshold). The general trend has been from a high threshold in 2008, to a medium threshold in 2012, and finally a low threshold in 2016. Through a combination of lessening enthusiasm for candidates and the candidates themselves exerting greater control over narrative and online voter engagement, the dynamic of popular mobilization on social media is a shift from active discourse to passive consumption of political information (2017, pp. 157, 172).

To quote Baumgartner \& Towner, "[in 2008] ...voters actively engaged social media outside the context of formal campaign and party organizations" (2017, p. 153). They created their own content promoting a candidate to be shared and gathered campaign involvement from friends through their own social networks. Entering 2012, the public displayed less innovation and engagement on social media while the campaigns increasingly developed new strategies to exert greater control over narrative and voters' online engagement. Essentially, social media had become "a new form of passing entertainment" (2017, p. 154). By the 2016 campaign, candidates were prone to "[flood] the social media zone with their own content, eclipsing the ability of voter-generated material to gain traction". Campaigns would "... actively seek to coordinate social media users' political engagement through their organizations rather than having users take the initiative, as occurred in 2008". All the while "...voters were less likely to create and disseminate their own material as they were more inclined to monitor social media without comment or to respond to material posted by campaign and media elites" $(2017$, pp. 153-55, 172).

This rising passivity in conjunction with the recent allocation of political information gathering from traditional mediums to the personalized online could be interpreted as detrimentally affecting eligible voters' political information efficacy, which is "...the extent to which individuals believe they have the information necessary to meaningfully engage in political participation" (Schill \& Hendricks, 2018, p. 109). This ties in with Allcott and Gentzkow's (2017) premise of social costs of misinformation. In addition, the brevity, negativity, personal or character focus, and "going public" aspects of the most recent social media campaign use are exploitative of this political information efficacy, all serving as archetypal methods of a populist environment. 
The brevity feature of the 2016 US presidential election is not new, starting even before the Obama campaigns. Due to the twenty-four/seven mass media news cycles, brief sound bites became the more familiar presentations of politicians. Now, with the introduction of social media, especially twitter, compact messaging became an important political tool in and of itself; while not necessarily a significantly novel method of campaigning, the fact that this is occurring on social media without initial collaboration with traditional media is what is most important here. Twitter allows for, not exhaustively, brief campaign or poll updates, re-tweetable slogans such as "Hope and Change" or "Make America Great Again", and especially recently, rapid-fire insults and attacks that can help shape public opinion and policy (Farnsworth, 2018 , p. 7). These simple and often-times emotional messages effortlessly grab the attention of an easily distracted populous due to their entertainment value. In addition, there is a lessened degree of mediation with these new "sound-bites" being sent on social media and a much larger audience, with campaign tweets themselves also become news in mass media, again helping candidates shape public narrative.

An unfortunate tendency of a tweet's brevity is the ease of turning negative. The "rapid-fire insults" mentioned before are evidenced by President Trump's use of twitter as a bully-pulpit. Outside the deliberate cynicism from candidates is also evident among online users themselves, especially in ideologically isolated rooms. An example:

\begin{abstract}
[A] study of 39 million political comments on Reddit from January 2015 to January 2017 found that an increasing number of offensive posts that focused on political content appeared leading up to the 2016 election, a trend not seen in nonpolitical posts from the same period. Those offensive posts... were also more popular on the site (as measured by up-votes minus down-votes by those reacting to the posts) than comments that were not deemed offensive. ... Rewarded behavior is repeated behavior, and so the forwarding of nasty comments online should lead to even more such commentary on social media (Farnsworth, 2018, pp. 135-36).
\end{abstract}

Recall Mazzoleni, Stewart, and Horsfield's (2003, p. 219) first step of populist mobilization, the "indirect increase of society's sense of psychological insecurities"; the political cynicism and character negativity online which caught and flourished among the right during Obama's campaigns and tenure possibly enabled this practice under Trump towards a conservative populist electoral success.

Maintaining a positive personality and character appearance is also an important tool in contemporary campaigning. President Obama utilized social media to this end to project himself as both the messenger calling for 'hope and change' and the personification of that mantra. He would regularly post instances of his appearance on non-politically oriented programs showcasing a friendly and empathetic demeanor or even a "regular-ness" such as showcasing his college basketball tournament picks. For more policy specific exercises, the Obama campaigns were keen on reaching out to the public to explain policy challenges and initiatives through the additional use of YouTube videos and online peer-to-peer communication efforts, all emphasizing Obama's personal qualities (Farnsworth, 2018, p. 6).

In comparison, the Trump campaign especially focused on signs of adoration, combining images of rallying supporters (and hyperbolic rhetoric to over quan- 
tify the extent of this) and for example, an image of President Trump addressing a joint session of Congress, with Vice President Pence and House Speaker Ryan standing and applauding the new president, on his White House page once in office (Farnsworth, 2018, pp. 131-33). In addition, his colloquial social media messages left voters with the impression that he was speaking directly to them. Moreover, candidate Trump would "go public", a two-step plan involving generating controversy and then attacking journalists, the media as a whole, and fact checkers, cementing a personification as the only one who could be trusted (Baumgartner \& Towner, 2017, p. 200).

In summary of these social media techniques, “... posts were 'social-media-genic' and designed to be shared, clicked, and commented upon" (Schill \& Hendricks, 2018 , p. 21). Through brevity and a focus on the personal, populist candidates easily provide the passing entertainment needed to gather a following in today's political arena. Further, incivility and the enablement of passivity online proved to be a successful method for right-wing populism whereas active engagement is more effective for those leaning left. These propositions were given credence in a research study by Jacob Groshek and Karolina Koc-Michalska (2017), in "Helping populism win? Social media use, filter bubbles, and support for populist presidential candidates in the 2016 US election campaign".

\section{Concluding remarks}

Twenty-first century populisms are unique in that they utilize social media in mobilization. While traditional forms of media are of course not irrelevant, the introduction of this new "personalized" medium may present a new era of politics, especially in the context of the US presidential campaign. As this phenomenon is contemporary, future analytical literatures will be necessary to better understand these developing events. In addition, as this article takes from a study on the use of social media from 2008-2016, it will be interesting to analyze how those trends continue to develop. Comparatively, while the claim here is only relevant to election of the US President, it may not be implausible to draw a connection between the rise of populist leaders on the world scale and the use of social media in other countries.

Reflecting, it should be noted that this article does not aim to explain how to address the "problem" of populist enablement, nor if it even is a "problem;" rather, what is important is the establishment that social media provides a connection between US presidential campaigns and twenty-first century populism. The most significant here is the amendment of Mazzoleni, Stewart, and Horsfield's description of populist mobilization to include social media and bring to attention the need to better understand the implications of social media on the four phases, for which more research will be necessary.

One example is whether this introduction of social media diminishes expectation during the final two phases. Due to online usage's seeming expedition and facilitation of a populist in the first two, it may become possible to never reach the decline phase but stay in the established. Moreover, entering that established phase may also have new significance via achieving legitimacy but being able to carry-over and maintain the spectacle in perpetuum. Another is extending a "pseudo" campaign once elected through the populist's tenure; social media would allow eligible voters 
to be subjugated to the anxieties brought by the ground-laying and insurgent phases continuously to the official re-election campaign.

Further, social media enables twenty-first century populisms in that emotional biases are triggered towards the benefit of leaders. It adds a characteristic of ochlocracy with heightening outrage from viral posts and videos into uncivil discourse against private individuals, citizen or official, incorporating harassment and a distancing response from private enterprises. While populist candidates are indeed assisted in garnering attention and setting a narrative by social media, the participatory function of the population cannot be understated either.

Finally, the conjunction of social media and politics may have completely redefined the role of the citizen. During these past, and probable future, instances of contemporary populisms, political information has been commodified by social media. In other words, populism and social media now creates the political to be consumed. The reach of the political sphere has been expanded by social media to define a person's subjectivity. This political subjectivity is becoming a commodity through the consumption of yourself by oneself online - the endpoint of the "DailyMe".

The majority of people's opinions were kept to themselves before but are now shown externally through "likes" and sharing of posts. Modern political parties sustain their followings online through the use of hashtags and individual politicians now gain or lose favor through his or her online performance. The developing self-categorizing and passive-consumptive trends in the online sphere are significantly affecting the way eligible voters prepare themselves to enact a properly informed participation in elections. Developing during the Obama era a decade ago to now the surprise Trump election results, the political spectacle on social media is undoubtedly a powerful force in modern day populisms.

\section{Acknowledgments}

I would like to dedicate this article to Dr. Juan Escourido for his guidance and support in its creation a year ago, and for his encouragement in seeking publication, and to give special thanks to Dr. Magda Giurcanu for her assistance with revising a previous version and presenting at the 2018 State of North Carolina Undergraduate Research and Creativity Symposium. I would also like to recognize the editors and blind reviewers for their much-appreciated commentary and cooperation.

\section{References}

Allcott, H., and Gentzkow, M. (2017). Social media and fake news in the 2016 election. Journal of Economic Perspectives, 31 (2), 211-36.

Baumgartner, J. C. \& Towner, T. L. (2017). The internet and the 2016 presidential campaign. Lanham, MD: Rowman \& Littlefield Publishing Group, Inc.

Farnsworth, S. J. (2018). Presidential communication and character: White house news management from clinton and cable to twitter and trump. New York, NY: Routledge.

Gottfried, J. \& Shearer, E. (2016). News use across social media platforms 2016. Pew Research Center. Retrieved from http://www.journalism.org/2016/05/26/news-useacross-social-media-platforms-2016. 
Groshek, J. \& Koc-Michalska, K. (2017). Helping populism win? Social media use, filter bubbles, and support for populist presidential candidates in the 2016 US election campaign. Information, Communication \& Society, 20 (9) 1389-1407.

Harcourt, B. E. (2015). Exposed: Desire and disobedience in the digital age. Cambridge; London, UK: Harvard University Press.

Margetts, H., Yasseri, T., Hale, S. \& John, P. (2015). Political turbulence: How social media shape collective action. Princeton, NJ: Princeton University Press.

Mazzoleni, G., Stewart, J. \& Horsfield, B. (Eds.). (2003). The media and neo-populism: A contemporary comparative analysis. Westport, CT: Praeger Publishers. Praeger Ser. in Pol. Comm.

Mudde, C. \& Kaltwasser, C. R. (Eds). (2012). Populism in europe and the americas: Threat or corrective for democracy? Cambridge, UK; New York, NY: Cambridge University Press.

Richardson, G. W., (Ed.). (2017). Social media and politics: A new way to participate in the political process. Santa Barbara, CA: Praeger.

Schill, D.J. \& Hendricks, J. A. (2018). The presidency and social media: Discourse, disruption, and digital democracy in the 2016 presidential election. New York, NY: Routledge.

Sunstein, C. R. (2017). \#Republic: Divided democracy in the age of social media. Princeton, NJ: Princeton University Press. 